DE DE GRUYTER

OPEN

Polish Cartographical Review

Vol. 47, 2015, no. 4, pp. 225-239

DOI: $10.1515 /$ pcr-2015-0015

KATARZYNA LISEK

Przysieki

KAMIL NIEŚCIORUK

University of Life Sciences in Lublin

kamil.niescioruk@up.lublin.pl

\title{
The cartographic methods of presentation and GIS tool in analysis of historical data on the example of Great War cemeteries in southern Poland
}

\begin{abstract}
The paper deals with the application of Geographic Information System software in cartographic data presentation in the field of historical data mining. Lists of soldiers buried in the I world war cemeteries near Jasło were used. The prepared database helped to create series of maps, mainly diagram maps, that serve as a useful statistical and demographic characteristics of the phenomena. The authors stressed advantages of the solution used and the usefulness of historical data in spatial database preparation process. The shortages of the GIS software itself were also pointed out, especially as long as cartographic editing and methodology principles are concerned.
\end{abstract}

Keywords: cartographic method of research, GIS, war cemeteries, world war

\section{Introduction}

Through ages the reception of death and dead changed and a whole spectrum of emotion was involved, from fear through sadness to joy and even - in a modern pop culture - fun (S. Tanaś 2013).

The sign of human attitude toward the subject is, among other, the way they refers to their deads. It is, in many cultures, manifested in material way on cemeteries. Hence the cemeteries are a part of cultural heritage, being much more than just a burial place (J. Kolbuszewski 1996). They tell about the tradition, believes and material culture of a nation or local community.

The 20th century was the period of two great wars. They, in a natural way, left the battlefields scattered with graves and memorial cemeteries which commemorates the victims of that time. Such places are of interest of many different groups now and can even be seen as a specific tourist attraction (so-called thanatotourism). S. Tanaś (2013, p. 168) classifies motivations for thanatotourism into eight groups - four of sacrum and four of profanum. They can be referred to not only tourism, but the interest in cemeteries in general. In case of war cemeteries sacrum motivation involves identity (discovering the past and ancestors), commemorate and, to some extent, empathy with little religious motivations. The profanum motives are these of knowledge - cognition (of history and culture) and a little of curiosity (visiting interesting place) with no emotion (of fear) or entertainment motives. Cognition and identity may be understood as motives causing the fact cemeteries are a subject of the scientific research. What is presented in this paper can be seen as necrogeography - part of cultural geography, seeing the burial place as an element of landscape, socio-cultural and functional space. Many of such works use war-time graves as an example, no matter what aspect is analysed. It can be, as mentioned, tourism of different kinds (P. Slade 2003, C. Winter 2011), landscape and small-area compositions (K. Grygorowicz-Kosakowska 2012) and general and regional approach (K. Ruszała 2008).

Cartographic method of research as defined by K.A. Saliszczew (1998) is a standard approach in geography and cartography, now often implemented by wide range of specialists using GIS. It is not only the tool to analyse, but also to describe the reality using maps and acquiring information as a result of observing part of this reality shown on cartographic 
materials (K.A. Saliszczew 1988, pp. 265-266). The GIS software significantly fasten (and often facilitate) both cartographic presentation and analyses of phenomena (P.A. Longley et al. 2006). By analyses one should understand the broad spectrum of procedures, from simple selections to complex modelling (R. Olszewski 2007). W. Żyszkowska (2003) classifies GIS analyses into basic (data integration and selection), topological (spatial), cartometric measurements, attribute manipulations (grouping, statistics), analyses of spatial distribution and volume and generalisation. This classification is open, especially in a changing environment of methods and tools. What is important is the fact that for GIS maps are vital, even if some analytic and data-manipulation functions can work with no visualisation of results (D. Gotlib 2007) and if some of presentation tools have a lot of shortcoming in terms of cartographic methodology.

Geographic Information System let one, in general, store, transform, analyse and visualize all kinds of spatial data. What is important is the fact that "spatial" does not necessary mean "a space up to date", as these information can be historic, describing situations, relations and space from the past. Spatial presentation of past data can reveal new relations, clues and address new research question. This fact is well-known to historians who often use maps as well as to geographers. The recent decade sees a significant growth of research on the joint field of spatial geography and textual history, understood as one, new research field - historical geography (A.R.H. Baker 2003), popularized by the development of GIS (B. Szady 2013).

\section{The goal and the subject of research}

The aim of this paper is to apply the cartographic method of presentation to analyse the spatial phenomena of socio-military aspects of the I world war cemeteries and evaluate the possibility to use GIS tools in this field. GIS often serves as a mechanism to present information on a single war cemetery, especially in an on-line version. It, however, in most cases lacks deeper analysis of spatial (answering "from where" question) and military ("what rank and unit") attributes. In case of war cemeteries they are of great interest, especially when one consider that both world wars, as the name suggest, involved soldier from different places fighting, dying and being buried far from their homes. The work presents what are the advantages and shortages of using maps and GIS tools to analyse the above mentioned data on the example of a dozen of the I world war cemeteries near Polish town of Jasło.

\section{The area of research}

The selected cemeteries are located in four communes: Dębowiec, Jasło, Kołaczyce and Skołyszyn in Jasło county, south-eastern Poland. It was the area of the II Grave District of Jasło, as organized by the Austro-Hungarian Department of War Time Graves. Of about 30 cemeteries in the district, twelve were included in the analysis. They are shown on figure 1 and are as follow: Bączal (also known as Skołyszyn, no. 27), Bierówka (no. 20), Bieździedza (no. 40), Cieklin (no. 14), Harklowa (no. 15), Jabłonica (no. 28), Jasło (no. 22), Osobnica (no. 16), Podzamcze (or Jasło-Podzamcze, no. 36), Sławęcin (no. 26), Święcany (no. 30) and Warzyce (no. 21).

The cemeteries were organized and designed after May 1915 Gorlice - Tarnów offensive (sometimes referred to as the Gorlice battle) in what was then Austro-Hungarian Galicia region. German and Austro-Hungarian armies pushed Russian forces back towards the east. Over 60 thousand of death bodies ${ }^{1}$ of both belligerents were buried in cemeteries build with money raised in the Austro-Hungarian Empire. The whole project was coordinated by the above mentioned Department of War-Time Graves and well-known architects were involved, including Slovak Dušan Jurkovič and German Hans Mayr (M. Luboński 2007). What is interesting, even prisoners of war with proper qualifications worked here (J. Schubert 2015). All cemeteries analysed in this paper were designed by German lieutenant Johann Jäger, artistic director and, later, head of the Grave District of Jasło. His works are defined as "typical Teutonic" and - in terms of artistic values - not rated as high as these highly admired of Jurkovič (O. Duda 1995).

\footnotetext{
1 The number differs, depending also on the methodology and the period included, from 1914-1915 only (GorliceTarnów offensive) to a whole war as well as the fact of including all bodies or exhumed and moved to a new cemetery only. It gives numbers from 43,000 (R. Frodyma 1995) to 70,000 (O. Duda 1995, J. Schubert 2015) soldiers buried.
} 
However, it is not a rule and some of his projects are simply aesthetic and well-composed with the landscape (fig. 2).

\section{Data acquisition and reliability}

The operation of the cemeteries construction was a serious undertaking. Beside designing around 400 objects, tens of thousands of soldiers dead bodies were exhumed and - as long as it was possible - identified to a maximum extent (R. Frodyma 1995). Available archive identification materials were compiled by several authors including works dealing only with the subject (to mention a three-volumes work by R. Frodyma $(1995,1997,1998)$ and

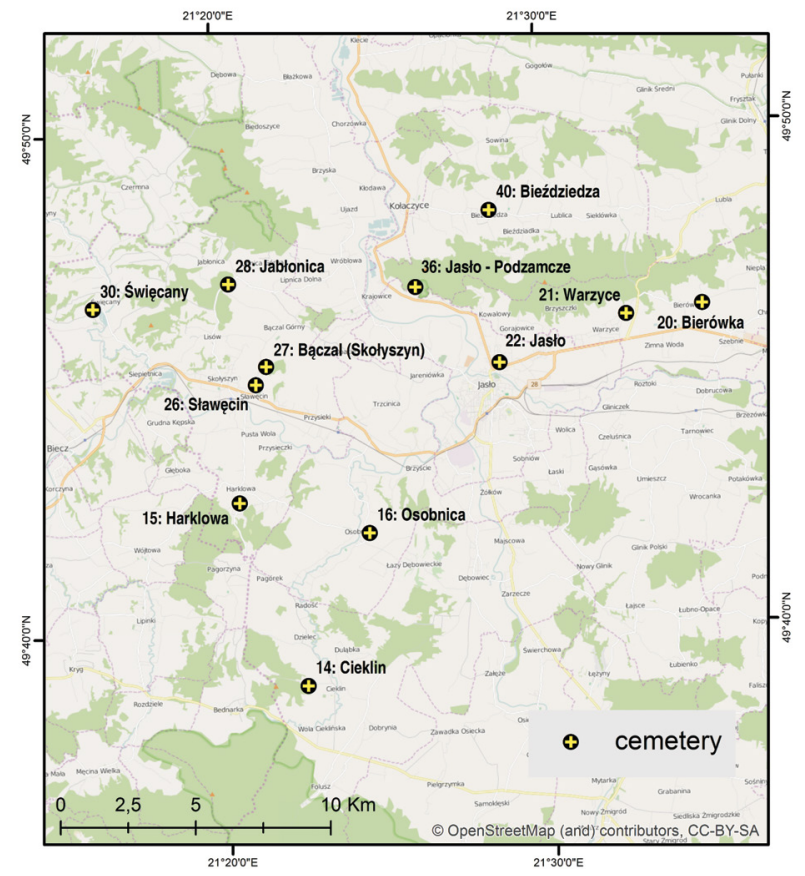

Fig. 1. Location of the analysed cemeteries

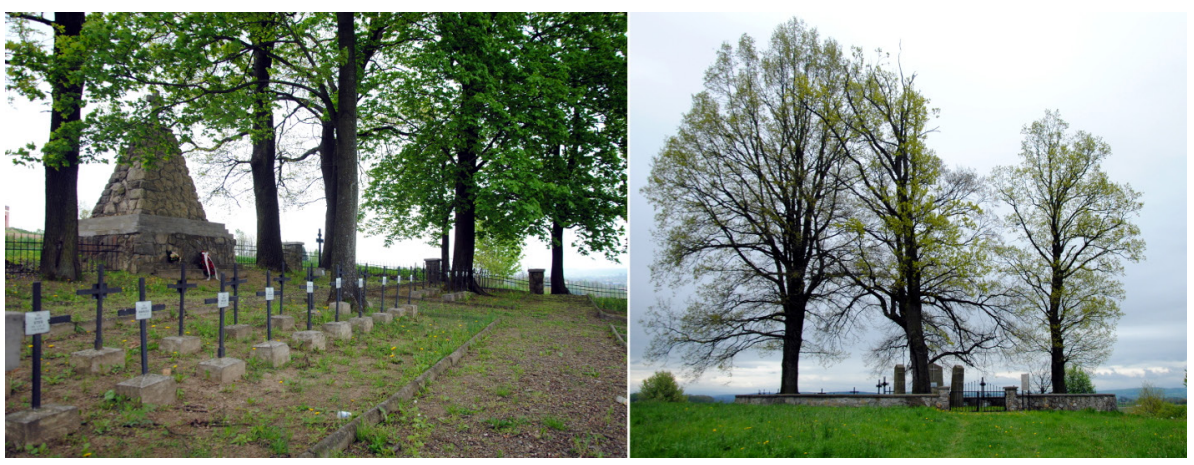

Fig. 2. Johann Jäger projects: Sławęcin no. 26 (left) and Bierówka no. 20 (right). Bierówka can be a good example of a landscape composition, located on a hillock over a local road and with oaks planted during the cemetery designing (they are natural monuments now) 
a complex, also three-volumes soldier list by J. Drogomir (1999, 2002, 2005)), as well as more general regional war cemeteries works (B. Uliasz 2006). There is also a number of internet sites about Galicia and the I world war cemeteries (W. Fronczak 2007, M. Łopata 2007). All these works contains different data - some of them are more general, while the other contain very detailed information which, however, differs from work to work. What is even more misleading, some cemeteries grave-tables fitted after their renovations contain data not found on printed lists. This caused a serious problem when choosing the data source for this paper. After analysis the list by J. Drogomir (1999), based on field and, mainly, archival data were selected, while it is worth mentioning that W. Fronczak (2007) on-line list seems to be, at least in some aspect, a worth considering extension of the mentioned J. Drogomir work.

\section{Data preparation}

List of soldiers was set in a form of table containing, among other, name and surname, army, military rank and unit. None of them were filled in $100 \%$ for analysed cemeteries. For most cemeteries army information was given except a few cases, while name, rank and unit were often absent (however, a unit was given more often than a rank). While the German and Austro-Hungarian army data were collected to a satisfactory extent, the data about Russian soldiers were almost in all cases limited to the army information, with no name, unit nor rank. It is worth stressing however that death soldiers of enemy army were treated with respect, also on the official level of special guide issued by the Department of War-Time Graves and the Austro-Hungarian Ministry of War (J. Schubert 2015).

All these data were extracted and sorted using Excel spreadsheet programme of Microsoft Office 2010 package. After sorting them, the separate tables for selected data were prepared and used in ArcGIS 10.2.2 programme as external attribute tables for point shape file of cemeteries location. Beside these, OpenStreetMap, the free online geographic data were used as a base for resulting maps.

The battle of Gorlice took place from 2nd to 12th of May 1915 (M. Klimecki 1991), but the soldiers buried on cemeteries are not only the victims of this offensive, as there are some burials of earlier as well as later dates. While all death identified by date on Bierówka, Cieklin and Osobnica are of Gorlice-Tarnów offensive, the other cemeteries are not so homogenous. Single other dates burials are noted in Bieździedza (soldier who died in July 1915), Harklowa, Jabłonica and Warzyce (all of December 1914), 2 are buried in Święcany (December 1914) and 4 in Skołyszyn (December 1914 as well). The most diversified are cemeteries of Sławęcin and Jasło no. 22. On the former, only 3 of 12 identified soldiers died during the offensive and there are 8 of December 1914 and 1 of January 1915. The later, Jasło cemetery, contains bodies of not only direct battle victims, but also soldiers who died in field hospital in Jasło area (some of May 1915, but also late May 1915, June 1915, December 1914 and even May 1917).

\section{The analyses}

The first stage of data investigation was a spatial distribution of armies per cemetery. Each object was assigned a table with number of burials of each army and these data were visualized using circle diagram method, which is often found in GIS packages under 'proportional/graduated symbols'. The result can be seen on figure 3.

Despite the above mentioned fact that Russian army list was the least detailed one, their soldier form the most numerous part of burials on many analysed cemeteries, especially these of the largest number of burials in general, like Jasło no. 22, Cieklin and Sławęcin. On smaller cemeteries proportion differs and the numbers are more balanced. What is interesting is the fact that the only cemetery with detailed information about Russian army soldiers (Warzyce) is the one with the smallest number of them (20, compared to 29 in next least numerous of Bieździedza and 555 in the most numerous of Jasło no. 22). Beside the three armies that were involved in the Gorlice - Tarnów, a few burials were, what can be seen on the map, not assigned to any of these armies. For Bierówka cemeteries they were twelve unknown soldiers, but there are clues to assign them to Austro-Hungarian army. In Jasło no. 36 and Bieździedza buried soldiers were of unknown army, respec- 


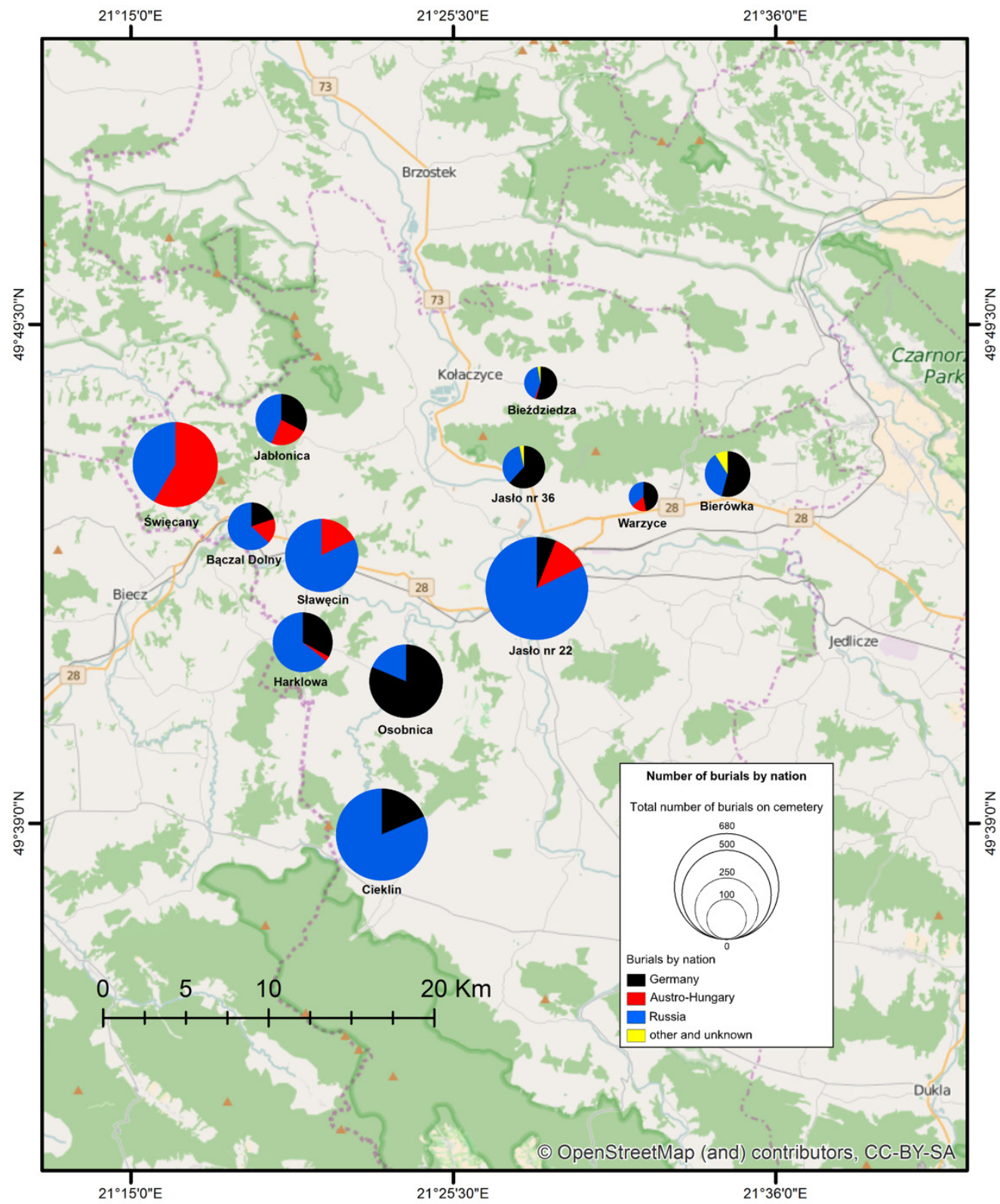

Fig. 3. Number of burials by nation per cemetery

tively four and two victims. The most interesting case is the Jasło no. 22 cemetery. Of four people buried there two are described as unknown civilians and one as the unknown (probably soldier). It was not rare for the unit to have unranked people among their staff (the lists contain for example a nurse or a coachman), but they were still a part of the unit. The two described above could even be local victims of the battle or war in general (this cemetery has some bu- 
rials of people who died in hospitals). The last of the deceased of this group is a soldier of the other than a three involved armies. It is the infantry regiment private of Serbian army, who died in November of 1916, one and a half year after the offensive. He was, probably, a prisoner of war (M. Łopata 2007).

The structural circle diagram map works here very well, showing both number and share of burials. The small diversity (only 4 types of data) and quite a significant numbers would justify using other type of diagram - bar charts, but the selected one works very well and is more elegant in terms of design compared to bars due to its more of a concise shape. The only serious problem with these diagrams is a legend generated by the software. It consists of a single example diagram with one value which explains nothing at all and does not allow to compare diagrams and discover quantitative relations. Additional works were needed to re-construct the legend and a simple diagram size explanation has been chosen. Due to limitations of graphic manipulation tools in GIS software, a vector graphic programme (Inkscape) was used.

Knowing the general structure of buried by nations, it is worth taking closer look at a military structure. The table characteristics of cemeteries contain information about military unit and rank. Both attributes can be presented on maps in different forms. The diagram method has been selected again, as it can show both number and structure in a convenient and elegant form. The data preparation stage showed that information are, as mentioned above, incomplete. Only a part of soldiers were given all data: name, rank and unit. This is the reason why the number of soldiers per army shown on figure 3 are not equal to number of soldiers shown on the following maps with ranks and units. For Austro-Hungarian and German army data are quite numerous. The most significant data completeness is observed in case of German army. Of 797 buried soldiers, 546 (68.5\%) has military rank given. Such a good situation is observed on both cemeteries where little Germans are buried and on these, where they are in big numbers. For example one German soldier buried in Sławęcin has a rank given (100\%), 39 of 41 (95\%) in Jasło no. 22 has this information and even on a biggest one Osobnica, where 283 Germans are buried the per- centage is quite high as for this number $-59 \%$ (169 identified soldiers). The Austro-Hungarian army is in a significant way less identified in terms of ranks. A total of $38.9 \%$ of soldiers has rank data given with as much as $79 \%$ in Jasło no. 22 and a few cases of little or no info ( 0 of 40 identified in Jabłonica and 2 of $25-8 \%$ in Skołyszyn). The Russian army, with the biggest number of buried on the analysed area (almost two thousand) has only seven $(0.35 \%)$ soldiers rank identified. In cases of all armies, the problem of ranks is also a problem of terminology, as the system varies from army to army and names tend to change. Simple translation of the name is not always explaining the equivalent of the rank in other army. The maps below uses both English and original ranks names. In case of the (most common) lowest military rank of private, soldiers of this rank were all counted as one type, without distinguishing the type of the regiment. For example in the Austro-Hungarian army infantry private was named: infanterist, honvéd, szeregowy etc. for infantry regiments and dragoner, husar, ulan for cavalry, kanonier for artillery and jäger for rifle regiments. This distinguishement was present also in higher ranks, but, as the most of the soldiers analysed in this paper were privates, were not needed. The reserve soldiers were treated as the regular army ones (hence reserve infanterist and infanterist were both counted as privates).

The German army ranks (fig. 4) confirm the above statement of domination of privates. Almost 80 percent of buried (and identified) soldiers on the analysed cemeteries were privates. Most cemeteries contain over $50 \%$ (and in many cases over $75 \%$ ) of privates. Only on Cieklin cemetery there is only 1 private of 31 German soldiers in total. The other troop rank - private 1st class (Gefreiter) is far less observed with no cemetery exceeding 10 such soldiers buried with maximum of 9 in, again, Cieklin. Almost ten percent of buried soldiers were in the rank of the lowest non-commisioned officer - corporal (Unteroffizier). They were dominant in Cieklin (39\%), quite numerous in Osobnica (13) and not present only on 3 cemeteries with rank identified burials. The other junior non-commisioned officer was sergeant (Feldwebel). Such soldiers were buried only on two cemeteries (Harklowa and Cieklin). The other ranks that are present in little numbers are deputy 


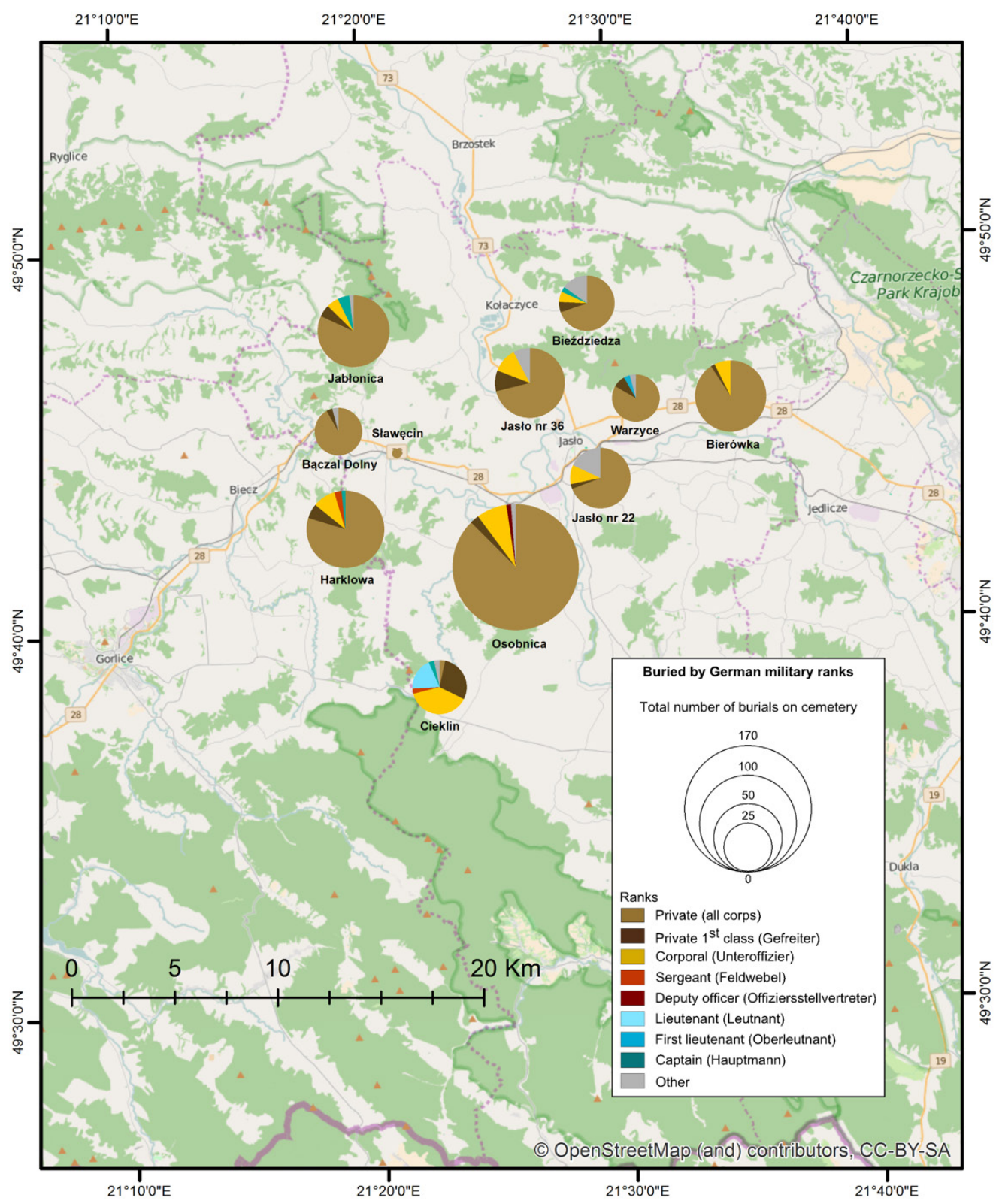

Fig. 4. Buried soldiers of the German army by military ranks

officer (Offizierstellvertreter, 2 in Osobnica) and officers: lieutenant (Leutnant, 6 in Cieklin) and first lieutenant (Oberleutnant, 1 in Warzyce). The highest recorded rank in the analysed cemeteries is captain (Hauptmann). There are
7 captains buried on analysed cemeteries with as much as 3 in Jabłonica. Of the ranks marked as "other", regiments members not being a typical soldiers are worth mentioning. There is one hornist, a coachman, one one-year vo- 


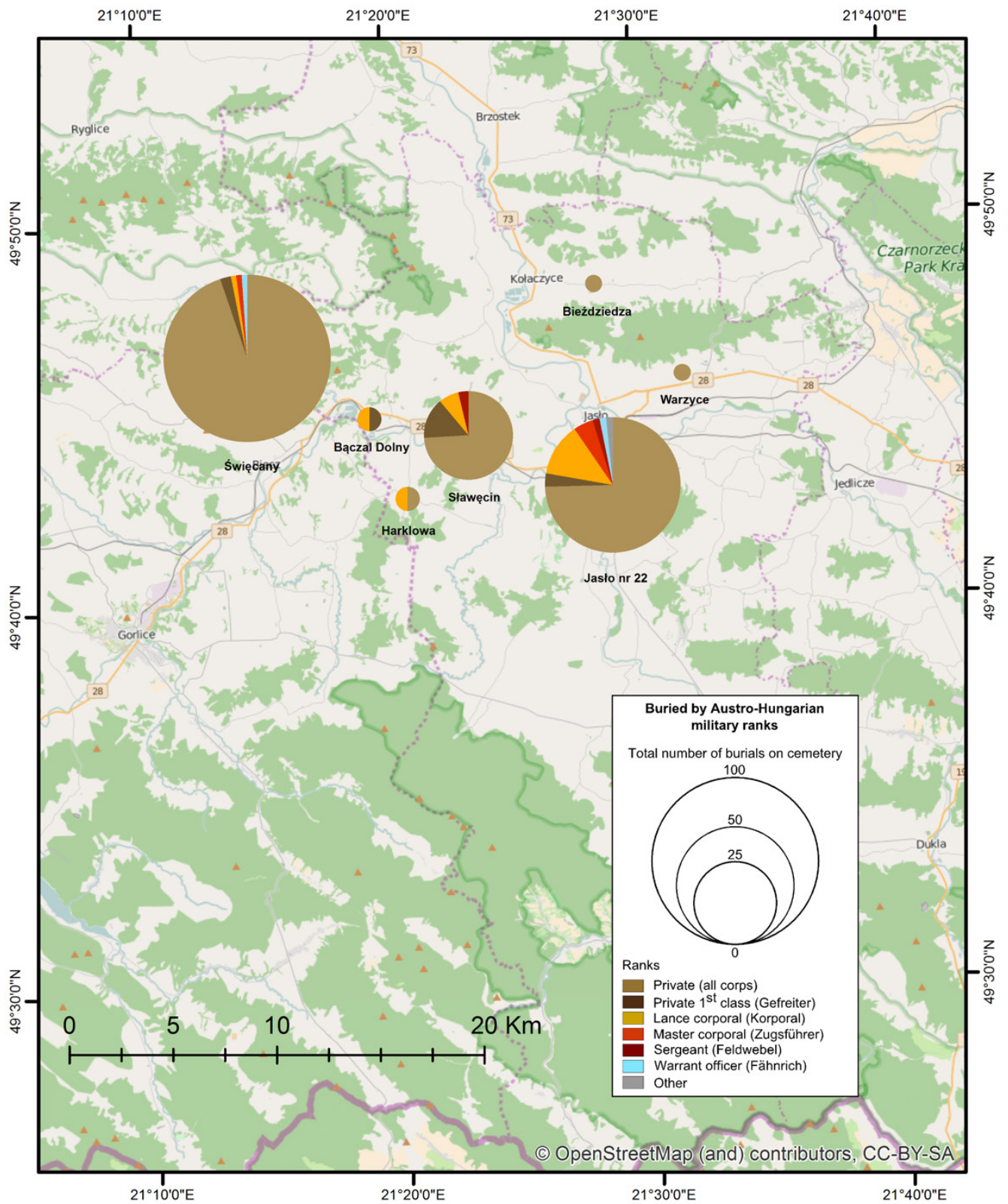

Fig. 5. Buried soldiers of the Austro-Hungarian army by military ranks

lunteer (Einjährig-Freiwiliger) and over a dozen of volunteers (Kriegs-Freiwilige).

For the Austro-Hungarian army (fig. 5) the domination of privates is even more evident as they form $84 \%$ of identified buried soldiers.
They are not present on Skołyszyn (Baczal) cemetery only. In Harklowa they stand for $50 \%$ (1 of 2) buried and on the rest of cemeteries the proportion is over $70 \%$. As in case of German army, the private 1st class (Gefreiter) is 


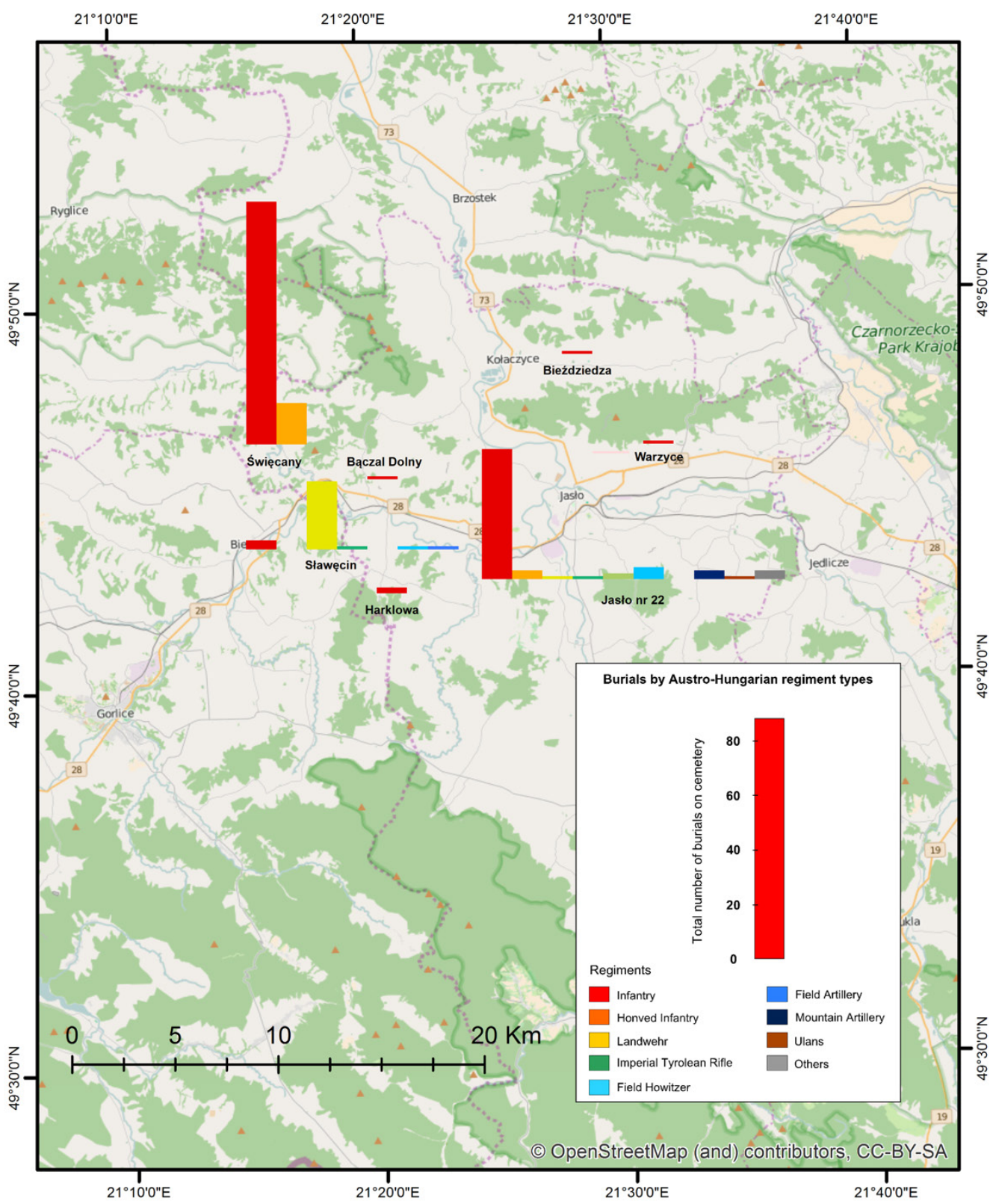

Fig. 6. Buried soldiers of the Austro-Hungarian army by regiment types

little less observed than lance corporal (Korporal) - respectively $4.7 \%$ and $6.8 \%$. The other non-commisioned officers observed are master corporal (Zugsführer, 3 in Jasło no. 22 and 1 in Święcany) and sergeant (Feldwebel, 1 in Jasło no. 22 and 1 in Sławęcin). The highest rank was warrant officer (Fähnrich) - 1 in Święcany and 1 in Jasło no 22.The category of "other" contains one nurse (Pflegerin) buried in Jasło no. 22. 
The least information is available for ranks of Russian army. Only 7 soldiers were identified. There is one private (in Jasło no. 22), one sergeant (фельдфебель, fel'dwebel, in Sławęcin), one ensign (прапорщик, praporščik, in Warzyce) and one captain (капитан, kapitan, in Skołyszyn). There are also 3 soldiers described in general as officers ( 2 in Jasło no. 22 and 1 in Skołyszyn). With so little information to present, the map was not prepared for these data.

The method of diagram works here very well as pie-charts are, again, compact and precise. However, additional works to improve the legend were needed again. These maps proves that German and Austro-Hungarian army soldiers were far better identified compared to Russians, what seems understandable according to the fact that cemeteries were constructed by the Austro-Hungarians.

The other information, after knowing the military ranks of soldiers, is about units they belonged to. This information stored in tables gives a lot of possibilities in analyses. The simplest one is visualizing each cemetery according to units of soldiers buried on it. The tables were analysed and each unit was grouped into regiment types of infantry, rifles, artillery, cavalry and other. The figure 6 shows the resulting map for the Austro-Hungarian army. It is no surprise to see the domination of infantry regiments. Soldiers of these formations are buried on analysed cemeteries with a total number of 134 and as much as 82 in Święcany and 44 in Jasło no. 22. Honvéd and Landwehr (territorial army) infantry soldiers constituted respectively 17 and 26 with Święcany (Honvéd), Sławęcin (Landwehr) and Jasło no. 22 (both). The soldiers of the elite infantry regiments of Kaiserjäger (Tyrolean Rifle) were buried only in the number of two. Less than 10 buried soldiers were serving in artillery: field and mountain artillery and howitzer regiments. On the Jasło no. 22 cemetery there is one cavalry regiment soldier buried - of 5th Ulan Regiment from Hungarian city of Szombathely. The category of "other" on the same cemetery consists of soldiers of combat support arms (telegraph troops) and described as "of air forces" ("luft. esk.").

Similar situation of a domination of infantry regiments can be seen on figure 7 presenting the German army, while the troop types are far more diversified. There is a significant domi- nance of soldiers from Prussian regiments. Number of reserve regiments soldiers is over 280 with 167 in Osobnica solely. Regular Prussian Infantry Regiments are not that numerous -80 soldiers were buried on analysed cemeteries with over $50 \%$ of them in Cieklin. The total number of 230 soldiers of Berlin Grenadier Guards Regiments were buried on most of the described cemeteries. Imperial Prussian Grenadier Guards Regiments soldiers were buried in number of 143 with over 50 of them in Bierówka while the Imperial Prussian Grenadier Foot Guards Regiments soldiers are found mainly in Jabłonica (54 of total 87). The small number of 5 soldiers of Bayern Infantry regiments were buried in Jasło no. 22. The other formation of the German army have even smaller representation than in case of the Austro-Hungarian army. Only 3 soldiers of artillery regiments and one of cavalry (dragoons) were buried on the analysed area. The category of "others" consist of one sapper (Jasło no. 22) and two soldiers of Radfahr-Kompanie, bicycle company of infantry battalion (cemetery in Osobnica).

The map for Russian army was not prepared, again. It was caused by the very little number of data to present - the map would be very limited compared to both previous. Only one cemetery (Warzyce) data contains information about regiments and all identified soldiers were infantry regiments members. What is interesting, with only 8 such soldiers there are 4 regiments (numbers 241 to 244).

The method used on these maps is, as in case of rank, diagram, but completely different solution has been chosen. Instead of cumulative, structural circle diagrams, separate bars have been chosen. Circle diagrams are very elegant in graphic forms and show structure of a phenomena by proportion, but in case of significant dominance of one element it may be hard to read the rest if it forms only a few percent or less. That needs a much bigger diagram, which would not be good in terms of design. On the other hand, bars are also nonproportional in this case, as the data are such. Good scaling allowed using it however and the biggest ones (representing infantry) are not overwhelming the rest, while the smallest for artillery or cavalry are still easy to read. Bars are not cumulative in this case just to ease the reading process, showing each regiment type as a separate element. This solution works here quite well as 


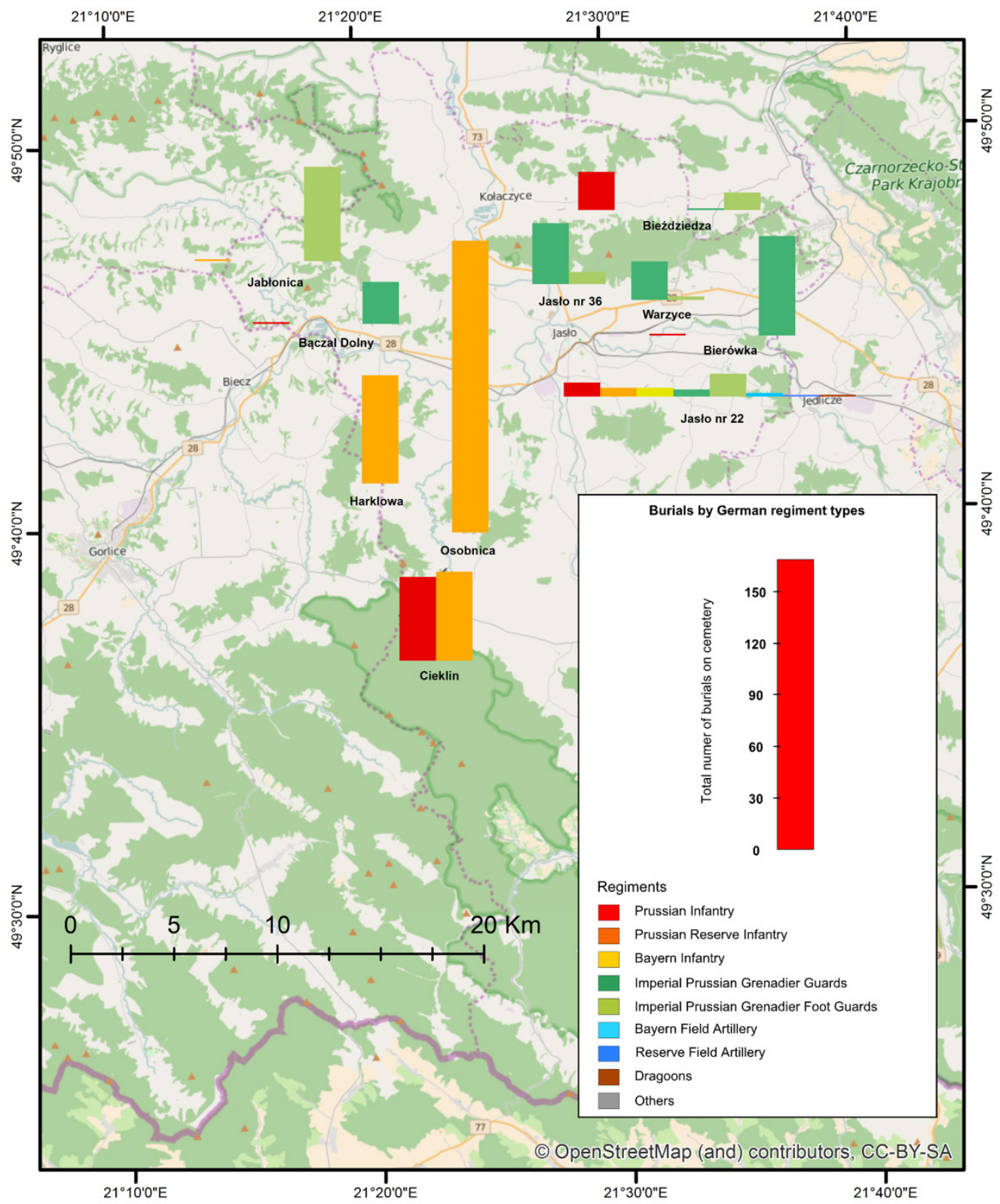

Fig. 7. Buried soldiers of the German army by regiment types

there are not many reference points (cemeteries) and even as much as nine bars side by side fits on a map. The only design problem is caused by the software used, which forms a gap in set of bars when there is a null value for a selected attribute. While it is not a problem for data with zero at the beginning or end of dataset (as in most cases of non-diversified cemeteries with infantry soldiers only), it is for these cemeteries of much more heterogeneous 


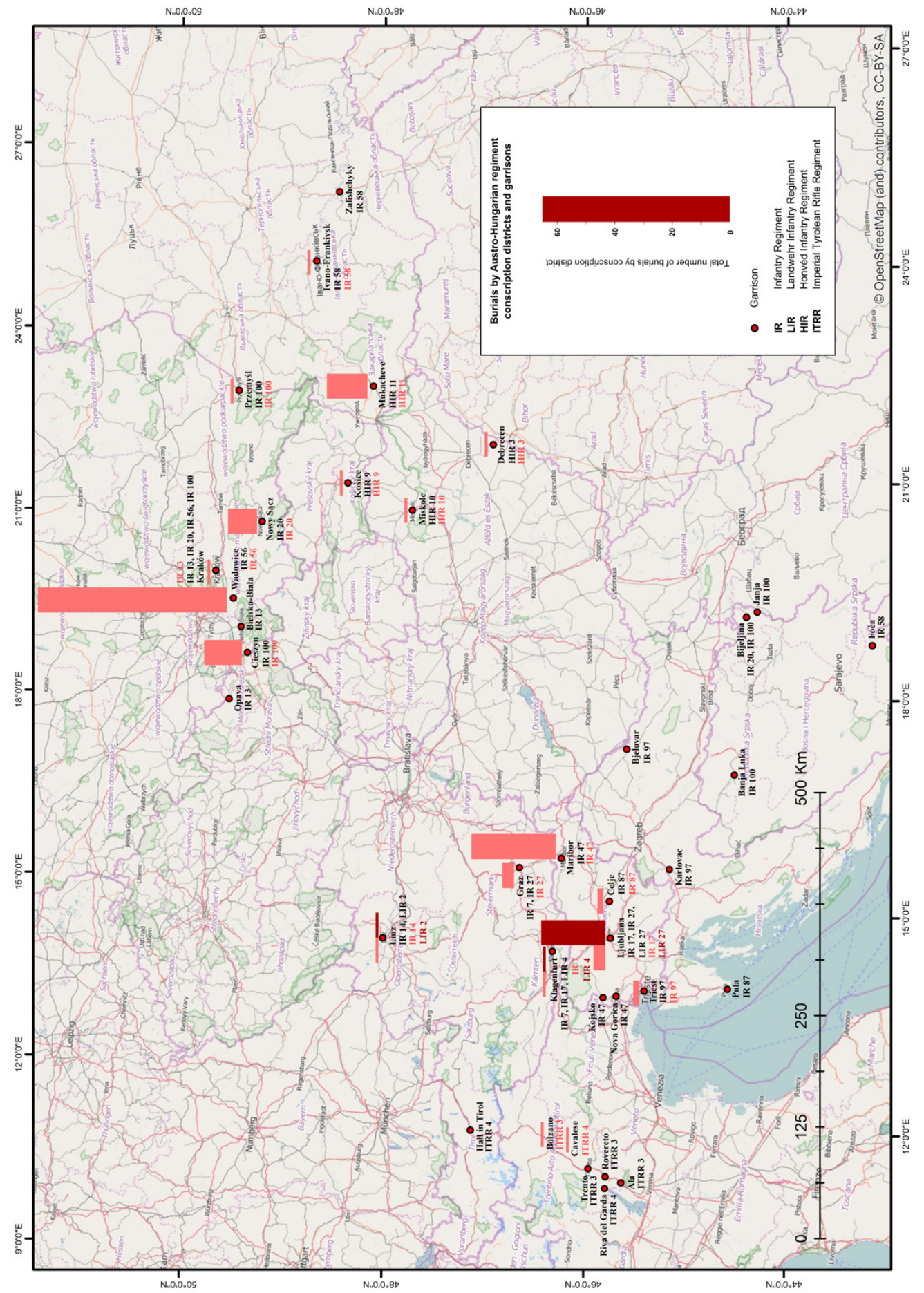

Fig. 8. Buried soldiers of the Austro-Hungarian army by conscription and garrison 
data. The problem can be observed on fig. 7 showing gap in diagrams for German regiments on Bączal cemetery. The other design problem seen here is the location of bars. They are aligned to reference point (location of cemetery) as well as the name (label) is. However, on diagrams with non-displayed (but used) null values, the visible part of diagrams are shifted left or right compared to a label. It can also be seen on the mentioned fig. 7 for diagrams with empty gaps, like Bieździedza or Bierówka. The problem can be solved in any graphic programme, but it has not been done to show the limitation of graphic outcomes and of application of cartographic principles in GIS software. What has been done was a legend designing in Inkscape to match the reader's expectations as the one generated by ArcGIS lacks even a basic information regarding the size of diagrams.

The most interesting aspect of the data present in tables is geographic origin of soldiers. The post-war geopolitical situation differed strongly from the belle époque period. New countries appeared on the map of Europe, some regaining independence after over a century of occupations. The most significant case is the one of the Austro-Hungarian dualistic monarchy. The country consisting of many, very different nations did not survived the war, but before it was one of biggest in Europe (its area was a little bigger than of a contemporary France) with multinational society. It was reflected in the structure of the army. In $191025.1 \%$ of soldiers were ethnic Germans, 22.8\% - Hungarians, $12.7 \%$ Czechs, $10.1 \%$ Croats and Serbs. The Italians, Jews, Poles, Romanians, Slovaks, Slovenians and Ukrainians formed a few percent each (J. Rydel 2001, tab. 4). It is easy to imagine that it was normal that in one army soldiers from completely different regions and cultures met. It is worth analyzing this structure. While the look into military ranks and units is interesting in technical aspects, the detailed look into the problem of where did the soldiers came from is the most revealing of this paper.

The figure 8 shows the central Europe with garrisons and conscription district seats for the infantry of the Austro-Hungarian army. The infantry has been chosen as a most numerous unit in the army. It clearly shows (especially with conscription districts) the geographic origin of soldiers taking part in the Gorlice offensive and buried in just 12 of hundreds of cemeteries of the area. The conscription districts used, what is important, are according to pre-war situation. During the war operation, regiments were supplied with local recruits.

The conscription areas concentrate in two regions. The first is northern Balkans and neighbourhood with the most significant cities of Maribor and Ljubljana, now Slovenia. The first is the seat of conscription district for Infantry Regiment 47 which 29 soldiers were buried on analysed cemeteries. The second town, modern capital of Slovenia, was the conscription area of Infantry Regiment 17 (4 buried soldiers) and Landwehr Infantry Regiment 27 (22 soldiers). The other cities that supplied soldiers involved in the offensive are: Slovenian Celje (IR 87), Italian Triest (IR 97) and Austrian Klagenfurt (IR 7, LIR 4) and Graz (IR 27). The second region of concentration is southern Poland, with a significant domination of Wadowice (IR 56 and 65 soldiers), Cieszyn (IR 100) and NowySącz (IR 20). The rest of the conscription districts involved in the analysis have single soldiers buried (except for Mukacheve with 14 soldiers), but spread from now western Ukraine (Ivano-Frankivsk for IR 58) to northern Italy Bolzano and Cavalese (Tyrolean Rifle Regiments 3 and 4).

While the spatial image of conscription districts shows how multicultural Austro-Hungary was, the location of garrisons shows how vast it was. The fig. 8 shows that for even just a dozen of analysed cemeteries it is clearly seen the army comprised of Poles, Slovaks, Ukrainians, Hungarians, Italians, Austrians and Slovenians. It is seen with high probability without checking the names or ethnicity written in the documents. Such lists of names may contain more information, but locations of conscription districts seats, where recruits were registered, are a good indicator of their geographic origin. In early XXth century, with far less mobility of people, it can also be linked with ethnicity.

Each regiment has its own conscription district, but soldiers were dislocated in at least three garrisons. For example soldiers of mainly of what one would call an Ukrainian ethnicity now conscripted for IR 58 in Ivano-Frankivsk were accommodated in barracks in Ivano-Frankivsk, where the staff was located too, in 
near Zalishchyky (now Ukraine) and in very distant Foča (today Bosnia and Herzegovina).

The garrisons are distributed more dense than conscription areas seats and spread more to the south, east and west. The mentioned Zalishchyky is the easternmost of the analysed with the also mentioned Foča being the southernmost. The garrison location most to the west is found in the Italian Tyrol town of Riva del Garda.

Such a distribution is no surprise in a country of size of Austro-Hungary. As well as it's multiethnicity seen on these maps.

\section{Summary}

The war always marks a land with graves of soldiers. The more global conflict is, the more diversified armies take part in it and, consequently, the more countries are witnesses of battles. Reading lists of buried soldiers with so different surnames lets one imagine this diversity. Maps serve as an extra add-on to this imagination, as they can show spatial aspect of the phenomena. The paper proved that data set in tables can be transformed into maps to visualize facts more clearly. The cartographic methods work well for showing the structure of selected variables and features like army, formation and military rank. Well-known and typical forms of presentation can be easily used here, with diagrams being the most common solution to present quantitative data. The GIS tools ease the process of map creation, thanks to data manipulation procedures as well as to possibility of using external sources of information. However, these tools have some limitations, what was clearly seen in case of bar diagrams. While the method is simple and basic in terms of methodology, its application in a software used is not perfect. The problem of including null values in set of bars is easy to overcome in any graphic manipulation software and even in the GIS itself, but the latter needs conversion to separate graphic objects. It means one lost a connection between database (attributes of objects) and graphic representation of it. It has not been done in the paper to show the mentioned limitation. On the other hand, a graphic software was used to improve the design on maps' legends, as the default solution used in the GIS programme was unacceptable.

To summarize map editing process, it is worth mentioning that OpenStreetMap project serves as a great example of external spatial data. It can be freely and easily used in many ways. The easiest solution is to implement the already-existing OSM map into a project, but it has some limitations observed in this paper. The layout and labelling of the online version of map is not always matching the layout of the map designed, so some background names may be cut half or unseen. To avoid such problems, OSM data may be downloaded as vector objects and visualised in the proper way in a project, but it needs much more effort.

The very positive aspect of results of the paper is the presentation of spatial distribution of origin of soldiers. As it was mentioned at the beginning of the summary, the graves can show a diversity, including spatial one. And it really is well-presented on the map, revealing not only the spatial context itself, but also, especially in case of the Austro-Hungarian army, ethnical phenomena. It can also lead to humanistic conclusion and reflection on the fact how war influence a life of a single human being, making a man join an army and fight far away from home. And that not everyone was lucky enough to go back, some stayed in an unknown land for ever, dying away from homes.

The presented paper has some limitation in data mining aspect. Only a few cemeteries were selected and they do not even form a grave district in full. So the final image of spatial distribution is not as rich as it could be and is not a real analysis of the full military aspect of the phenomena, being rather a test of the research approach and the tool. In addition, the paper can be treated as an encouragement to interdisciplinary research, as one of its goals was to test the possibilities of using cartographic methods to present topics on a border of tanathogeography and history. The paper is also an introductory, first step to further, much more deeper analysis of the subject with precise period, military unit and/or cemetery district selected. 


\section{References}

Baker A. R. H., 2003, Geography and history: bridging the divide. Cambridge: Cambridge University Press.

Drogomir J., 1999, Polegli w Galicji Zachodniej 1914-1915 (1918). Wykaz poległych i zmarłych pochowanych na 400 cmentarzach wojennych w Galicji Zachodniej. Tom 1. Tarnów: Muzeum Okręgowe w Tarnowie.

Drogomir J., 2002, Polegli w Galicji Zachodniej 1914-1915 (1918). Wykaz poległych i zmarłych pochowanych na 400 cmentarzach wojennych w Galicji Zachodniej. Tom 2. Tarnów: Muzeum Okręgowe w Tarnowie.

Drogomir J., 2005, Polegli w Galicji Zachodniej 1914-1915 (1918). Wykaz poległych i zmarłych pochowanych na 400 cmentarzach wojennych w Galicji Zachodniej. Tom 3. Tarnów: Muzeum Okręgowe w Tarnowie.

Duda O., 1995, Cmentarze z I wojny światowej w Galicji Zachodniej. 1914-1918. Warszawa: Ośrodek Ochrony Zabytkowego Krajobrazu.

Frodyma R., 1995, Galicyjskie cmentarze wojenne. Przewodnik. Tom 1. Warszawa - Pruszków: Rewasz.

Frodyma R., 1997, Galicyjskie cmentarze wojenne. Przewodnik. Tom 2. Warszawa - Pruszków: Rewasz.

Frodyma R., 1998, Galicyjskie cmentarze wojenne. Przewodnik. Tom 3. Warszawa - Pruszków: Rewasz.

Fronczak W. (ed.), 2007, Polegli w I wojnie światowej, www.polegli.forgen.pl (access: February 2015).

Gotlib D., 2007, Wizualizacja danych w systemach GIS. In: D. Gotlib, A. Iwaniak, R. Olszewski (eds), GIS. Obszary zastosowań. Warszawa: Wydawnictwo Naukowe PWN, pp. 58-61.

Grygorowicz-Kosakowska K., 2012, Formy przestrzenne pochówków wojennych z końca II wojny światowej jako element tożsamości miejsca na przykładzie gminy i miasta Czarnków. „Czasopismo Techniczne. Architektura” z. 7, pp. 303-313.

Klimecki M., 1991, Gorlice. Warszawa: Wydawnictwo Bellona.

Kolbuszewski J., 1996, Cmentarze. Wrocław: Wydawnictwo Dolnośląskie.

Longley P. A., Goodchild M. F., Maguire D. J., Rhind D. W., 2006, GIS. Teoria i praktyka. Warszawa: Wydawnictwo Naukowe PWN, 2006.

Luboński M., 2007, Wielka Wojna w Beskidzie Ni- skim. Operacja gorlicka 1915 i cmentarze wojenne. In: Luboński Marek (ed.), Beskid Niski. Przewodnik dla prawdziwego turysty. Pruszków: Rewasz, pp. 58-67.

Łopata M., 2007, Cmentarze I wojny światowej, www.cmentarze.gorlice.net.pl (access: February 2015).

Olszewski R., 2007, Analizy w GIS. In: D. Gotlib, A. Iwaniak, R. Olszewski (eds), GIS. Obszary zastosowań. Warszawa: Wydawnictwo Naukowe PWN, pp. 50-58.

Ruszała K. 2009, Trzy cmentarze z okresu I wojny światowej w Jaśle. In: M. Łopata (ed.), Materiały z konferencji naukowej „Znaki pamięci II - śladami I wojny światowej”. Gorlice 25.10.2008. Gorlice: Stowarzyszenie Aktywnej Ochrony Cmentarzy z I Wojny Światowej w Galicji „Crux Galiciae”, pp. 17-40.

Rydel J., 2001, W służbie cesarza i króla. Generałowie $i$ admirałowie narodowości polskiej w siłach zbrojnych Austro-Węgier w latach 1868-1918. Kraków: Księgarnia Akademicka.

Saliszczew K. A., 1998, Kartografia ogólna. Warszawa: Wydawnictwo Naukowe PWN.

Schubert J., 2015, Galicyjskie cmentarze wojenne. Historia, architektura, sztuka. In: J. Centek, S. Kułacz, K. Ruszała (eds), Bitwa pod Gorlicami. Studia z perspektywy stulecia. Gorlice: Urząd Miejski w Gorlicach, Gorlickie Centrum Kultury.

Slade P., 2003, Gallipoli thanatotourism. The meaning of ANZAC. "Annals of Tourism Research" Vol. 3, no. 4, pp. 779-794.

Szady B., 2013, Geografia historyczna w Polsce rozwój i perspektywy. „Studia GeoHistorica” nr 1, pp. 19-38.

Tanaś S., 2013, Tanatoturystyka. Od przestrzeni śmierci do przestrzeni turystycznej. Łódź: Wydawnictwo Uniwersytetu Łódzkiego.

Uliasz B., 2006, Cmentarze, kwatery i mogiły wojenne na Podkarpaciu. Tom 2 - Ewidencja pochowanych. Rzeszów: Stowarzyszenie Opieki nad Starym Cmentarzem w Rzeszowie im. Włodzimierza Kozło, Oficyna Pobitno.

Winter C., 2011, Battlefield visitors motivations: explorations in the Great War town of leper, Belgium, "International Journal of Tourism Research" 13, pp. 164-176.

Żyszkowska W., 2003, Analizy przestrzenne w systemach informacji geograficznej. „Polski Przegląd Kartograficzny" T. 35, nr 2, pp. 100-113. 